International Journal of Current Microbiology and Applied Sciences

ISSN: 2319-7706 Volume 10 Number 12 (2021)

Journal homepage: http://www.ijcmas.com

\title{
Effect of Cutting and Foliar Nutrition on Seed Yield of Sirukeerai (Amaranthus polygonoides) var. PLR 1
}

\author{
S. Pozhilarasi ${ }^{1^{*}}$ and R. Geetha ${ }^{2}$ \\ ${ }^{1}$ Department of Seed Science and Technology, Mother Teresa College of Agriculture, \\ Pudhukottai, Tamil Nadu, India \\ ${ }^{2}$ Department of Seed Science and Technology, Agricultural College and Research Institute, \\ Madurai, Tamil Nadu, India \\ *Corresponding author
}

\section{Keywords \\ Sirukeerai, cuttings, foliar spray, growth parameters and seed yields \\ Article Info \\ Received: \\ 10 November 2021 Accepted: 05 December 2021 Available Online: 10 December 2021}

\section{A B S T R A C T}

Sirukeerai (Amaranthus polygonoides) is an annual herb growing to a height of $80-90 \mathrm{~cm}$ starts flowering at 25 days and yielding green vegetable within 20 - 25 days. A field experiment was conducted at agricultural college and research institute to study the effect of cuttings and foliar nutrition on seed yield of Amranthus.. The cutting was taken to make different treatments i.e. $\mathrm{C}_{0}$ (without cutting), $\mathrm{C}_{1}$ (one cutting at 20 days after sowing) and $\mathrm{C}_{2}$ (two cuttings at 20 days and 35 days after sowing). The investigation resulted that number of foliage cuttings reduced the plant height of sirukeerai. The crop without cutting of foliage gave the maximum dry weight of plant per plant, crop growth rate and relative growth rate which was followed by one cutting and lowest performance was observed after two cuttings The increase in number of foliage cuttings of sirukeerai significantly increased the growth parameters of plant such as number of primary branches per plant, number of secondary branches per plant, number of leaves, number of spike per plant, and seed yield.

\section{Introduction}

Amaranthus is a leafy vegetable belongs to the family Amaranthaceae which comprises of 65 genera and 850 species. Approximately 25 species of Amaranthus have been reported in Asian region (Das, 2016). Four major types such as Mulaikeerai/Thandukeerai (Amaranthus tricolor), Araikeerai (Amaranthus tristis), Sirukeerai (Amaranthus polygonoides) and Grain amaranthus (Amaranthus hypochrondicus) are being grown in Tamil Nadu. Sirukeerai (Amaranthus polygonoides) is an annual herb, grows up to a 
height of $80-90 \mathrm{~cm}$ cut twice for green vegetable before maturity within a duration of 65-70 days. It is most resistant to shattering, well responsive to fertilizers and also suitable for growing throughout the year. In addition to being a good source of B vitamins, and minerals, amaranth is rich in fiber and protein. More important, it lacks gluten altogether, making it perfect for anyone struggling with gluten sensitivity.

Leafy vegetables are given importance for the foliage yield and not the seed yield or quality. Seeds are collected only after two or three cuttings for greens which lead to poor seed yield and quality. Pinching or cutting the top portion of the plant is a form of pruning which encourages branching in plants. Pinching breaks the apical dominance and induces development of lateral branches thereby increase the site for flowering stems to develop. The practice of pinching/pruning has proved to be effective in increasing the seed yield levels of different crops (Srilatha et al., 2015). Pinching will force the plant to produce more branches and flowering stems leads to increased seeds. Pinching is a common practice in amaranth grown for pot herbs to increase foliage through increased branching. Foliage cutting accompanied with adequate supply of nutrients at the appropriate time only leads to increased seed heads with proper filling. But there is very scanty literature available regarding pinching in amaranth for purpose of increasing seed yield. Hence the present investigation was proposed to study the effect of cutting and foliar nutrition on quality seed production of sirukeerai to improve the potentiality of the crop for more biomass as well as seed production.

\section{Materials and Methods}

Genetically pure fresh seeds of sirukeerai (Amaranthus polygonoides) var. PLR 1 obtained from Vegetables research station,
Palur, formed the base material for the study. Seeds were cleaned and graded using BSS 22 $\times 22$ wire mesh sieve prior to the commencement of the experiment. The crop was raised during 2017 following the recommended package of practices with the basal application of fertilizers @ 40:20:20 kg NPK ha ${ }^{-1}$. Cutting was imposed at 20 and 40 days after sowing with a plant height of approx. $30 \mathrm{~cm}$ and foliar spray was given twice after cutting at flowering \& peak flowering with an interval of 10 days as per the following treatment schedule.

The experiment was laid with a spacing of $20 \times 10 \mathrm{~cm}$ and in FRBD design with three replications and observations was recorded on five randomly selected plants. Plant height, total numbers of branches per plant, dry weight of plants were all measured at 20, 40 and 60 DAS. Yield parameters like number of pods plant ${ }^{-1}$, number of seeds pod $^{-1}$, seed yield and recovery percentages were assessed. Seeds were evaluated for its test weight, germination (ISTA, 2016) and dry matter production. The data gathered were analyzed statistically adopting the procedure described by Gomez and Gomez, 1984. Wherever necessary, percentage values were transformed to angular values, before carrying out the statistical analysis.

\section{Results and Discussion}

The plant morphology, seed yield and yield parameters were all highly influenced by cutting and foliar nutrition practices. Remarkable improvements were noticed due to cutting at 20DAS and foliar spray of nutrients on all plant growth parameters such as plant height, number of branches, plant dry weight and crop growth rate.

Cutting method generally used on young plants to encourage branching and in the present study also single cutting given at 20 
DAS reduced the plant height and increased the lateral branches to the tune of $13.5 \%$ at 60 days after sowing irrespective of foliar applications while those plants cut twice at 20 $\&$ 35DAS registered the least number of branches at all growth stages (Fig 1). Cutting enhanced the utilization of photosynthates by the crop for vertical growth might be reason for increased number of primary branches per plant and decreased plant height (Singh et al., 2013).

The deleterious effect of cutting at later date was balanced by the application of foliar nutrition where the plants sprayed with urea 2\% (14.30) or sulphate of potash @ 1\% (12.0) had recorded more branches even after cutting at advanced stages.

More branches were due to stimulated shoot auxillary buds which improved the number of side branches (Gopal, 2012). Foliar application of nutrients facilitates further rapid utilization of nutrients for the vigourous growth. Secondary branches were also increased due to foliar spray of nutrients.

Pinched plants usually took relatively more days to 50 per cent flowering compared to no pinching because of more production of secondary branches. But in the present study, secondary branches recorded was minimum (3-5) in all treatments including plants sprayed with nutrients (5-9), since the crop entered into reproductive phase shortly after cutting.

Increased branches results in increased vegetative growth and thus leaves. Cut once at 20 days after sowing resulted in the highest no of leaves (37. $03 \%$ ) but cut twice has resulted in low number of leaves (33.78\%), may be due decreased number of branches because of shorter duration of the crop after cuttings (Fig 1). But foliar application of urea $2 \%$ increased the number of leaves in both single and double cut plants compared to without cuttings. Adequate nitrogen supply may be the reason for the dark green colour of the leaves, vigorous growth, branching, leaf production and enlargement of the surface. Maximum number of leaves were recorded in coriander too when the cut plants were sprayed twice with urea@2\%.(Tiwari, et al., 2002)

The dry matter production estimation is essential for judging the optimum plant growth by distribution and re-distribution of biomass between different plant parts at various stages of growth (Rahman and Miah, 1995).

No cutting registered highest dry matter production at earlier stages and before harvest the trend was reversed and cutting once registered the highest dry weight of plants $(63.04 \mathrm{~g})$. Reduction in plant growth was to the extent of 11 to $15 \%$ in case of crop cut twice.

But the effect of defoliation was nullified to some extent $(8-26 \%)$ when plants were supplied with foliar nutrition. Urea @ $2 \%$ has improved the dry weight of plants to $39.03 \mathrm{~g}$ from $27.13 \mathrm{~g}$ in control even at 20 days after cutting.

Crop growth rate was found to be the highest with foliar application of urea $\left(16.64 \& 16.52 \mathrm{~g}^{-}\right.$ ${ }^{1} \mathrm{dsm}^{-1}$ ) as compared to control at both flowering and harvest stages irrespective of cutting once or twice (Fig.3).

Crop growth rate of amaranthus exhibited an increasing trend from vegetative to harvest stage followed by a decline thereafter. It was found to be highest at no cutting compared to single cutting or double cutting at both flowering and harvest stages. Similar trend was observed with relative growth rate also where Foliar nutrition with urea has registered higher relative growth rate $\left(0.013\right.$ to $0.041 \mathrm{~g}^{-1}$ $\left.\mathrm{m}^{-2} \mathrm{~d}^{-1}\right)$ compared to other treatments irrespective of cutting treatments (Table 1). 
Table.1

\begin{tabular}{|l|c|c|c|}
\hline \multicolumn{2}{|c|}{ Cutting Treatment } & \multicolumn{2}{c|}{ Foliar treatment } \\
\hline $\mathbf{C}_{\mathbf{0}}$ & No cutting + Seed crop & $\mathrm{T}_{1}$ & Salicyclic acid @ 50ppm \\
\hline $\mathbf{C} 2$ & Cutting once at 25 DAS + Seed crop & $\mathrm{T}_{2}$ & Urea @ 2\% \\
\hline $\mathbf{C}_{3}$ & Cutting twice at 25 \& 40 DAS + Seed crop & $\mathrm{T}_{3}$ & Ferrous sulphate and Borax @ 1\% \\
\cline { 3 - 4 } & & $\mathrm{T}_{4}$ & Sulphate of Potash @ 1\% \\
\hline & & $\mathrm{T}_{5}$ & Control \\
\hline
\end{tabular}

Table.2 Effect of cutting and foliar nutrition on Relative growth rate $\left(\mathrm{mg}^{-1} \mathrm{dsm}^{-1}\right)$ at 20 to 30 and 30 to 40 of day after cuttings Amaranthus polygonoides var. PLR 1.

\begin{tabular}{|c|c|c|c|c|c|c|c|c|}
\hline \multirow[t]{2}{*}{ Treatment } & \multicolumn{3}{|c|}{ 20-30 DAC $\left(\mathrm{mg}^{-1} \mathrm{dsm}^{-1}\right)$} & \multirow[t]{2}{*}{ Mean } & \multicolumn{3}{|c|}{ 30-40 DAC $\left(\mathrm{mg}^{-1} \mathrm{dsm}^{-1}\right)$} & \multirow[t]{2}{*}{ Mean } \\
\hline & $\mathbf{C}_{0}$ & $\mathrm{C}_{1}$ & $\mathbf{C}_{2}$ & & $\mathbf{C}_{0}$ & $\mathrm{C}_{1}$ & $\mathbf{C}_{2}$ & \\
\hline $\mathbf{T}_{1}$ & 0.010 & 0.010 & 0.008 & 0.009 & 0.012 & 0.011 & 0.0085 & $\mathbf{0 . 0 3 6}$ \\
\hline $\mathbf{T}_{2}$ & 0.015 & 0.015 & 0.014 & 0.015 & 0.018 & 0.016 & 0.0900 & 0.041 \\
\hline $\mathbf{T}_{3}$ & 0.007 & 0.007 & 0.007 & 0.007 & 0.009 & 0.008 & 0.0076 & $\mathbf{0 . 0 3 1}$ \\
\hline $\mathbf{T}_{4}$ & 0.013 & 0.012 & 0.012 & 0.012 & 0.015 & 0.014 & 0.0860 & 0.038 \\
\hline $\mathbf{T}_{5}$ & 0.007 & 0.006 & 0.004 & 0.006 & 0.007 & 0.006 & 0.0058 & 0.024 \\
\hline \multirow[t]{2}{*}{ Mean } & 0.011 & 0.010 & 0.009 & 0.010 & 0.012 & 0.011 & 0.0079 & 0.034 \\
\hline & $\mathbf{T}$ & $\mathbf{C}$ & \multicolumn{2}{|c|}{$\mathbf{T} \times \mathbf{C}$} & $\mathbf{T}$ & C & \multicolumn{2}{|c|}{$\mathbf{T} \times \mathbf{C}$} \\
\hline SEd & 0.00018 & 0.00014 & \multicolumn{2}{|c|}{0.00031} & 0.00049 & 0.00038 & \multicolumn{2}{|c|}{0.00086} \\
\hline CD $(0.05)$ & $0.00037 * *$ & $0.00029 * *$ & \multicolumn{2}{|c|}{$0.00064 * *$} & $0.00101 * *$ & $0.00078 * *$ & \multicolumn{2}{|c|}{$0.00175 * *$} \\
\hline
\end{tabular}


Table.3 Effect of cutting and foliar nutrition on seed yield of Amaranthus polygonoides var. PLR 1

\begin{tabular}{|c|c|c|c|c|c|c|c|c|c|c|c|c|}
\hline \multirow[t]{2}{*}{ Treatment } & \multicolumn{3}{|c|}{ Seed yield( g/ plant) } & \multirow[t]{2}{*}{ Mean } & \multicolumn{3}{|c|}{ Seed yield (g/plot) } & \multirow[t]{2}{*}{ Mean } & \multicolumn{3}{|c|}{ Seed yield $(\mathrm{kg} / \mathrm{ha})$} & \multirow[t]{2}{*}{ Mean } \\
\hline & $\mathrm{C}_{0}$ & $\mathbf{C}_{1}$ & $\mathbf{C}_{2}$ & & $\mathbf{C}_{0}$ & $\mathbf{C}_{1}$ & $\mathbf{C}_{2}$ & & $\mathrm{C}_{0}$ & $\mathbf{C}_{1}$ & $\mathbf{C}_{2}$ & \\
\hline $\mathbf{T}_{1}$ & 5.37 & 5.71 & 4.24 & 5.10 & 590.7 & 628.1 & 466.4 & 561.73 & 656.3 & 697.88 & 518.22 & 624.13 \\
\hline $\mathbf{T}_{2}$ & 6.12 & 6.73 & 5.24 & 6.03 & 673.2 & 740.3 & 576.4 & 663.34 & 748 & 822.55 & 640.44 & 736.99 \\
\hline $\mathbf{T}_{3}$ & 4.46 & 5.26 & 3.29 & 4.33 & 490.6 & 578.6 & 361.9 & 477.03 & 545.11 & 642.88 & 402.11 & 530.03 \\
\hline $\mathbf{T}_{4}$ & 5.56 & 5.88 & 4.86 & 5.43 & 611.6 & 646.8 & 534.6 & 597.6 & 679.55 & 718.66 & 594 & 664.07 \\
\hline $\mathbf{T}_{5}$ & 3.78 & 4.46 & 2.81 & 3.68 & 415.8 & 490.6 & 309.1 & 405.16 & 462 & 545.11 & 343.44 & 450.18 \\
\hline \multirow[t]{2}{*}{ Mean } & 5.05 & 5.60 & 4.08 & 8.19 & 556.38 & 616.88 & 449.68 & 540.97 & 618.19 & 685.41 & 499.64 & 601.08 \\
\hline & $\mathbf{T}$ & C & \multicolumn{2}{|c|}{$\mathbf{T} \times \mathbf{C}$} & $\mathbf{T}$ & C & \multicolumn{2}{|c|}{$\mathbf{T} \times \mathbf{C}$} & $\mathbf{T}$ & C & \multicolumn{2}{|c|}{$\mathbf{T} \times \mathbf{C}$} \\
\hline SEd & 0.045 & 0.0348 & \multicolumn{2}{|c|}{0.0779} & 7.164 & 5.549 & \multicolumn{2}{|c|}{12.409} & 6.763 & 5.239 & \multicolumn{2}{|c|}{11.71} \\
\hline $\mathrm{CD}(0.05)$ & $0.0922 * *$ & $0.0714 * *$ & \multicolumn{2}{|c|}{$0.1597 * *$} & $14.676^{* * *}$ & $11.368 * *$ & \multicolumn{2}{|c|}{$25.420 * *$} & $13.855^{*} *$ & $10.73 * *$ & \multicolumn{2}{|c|}{$23.99 * *$} \\
\hline
\end{tabular}

Fig.1

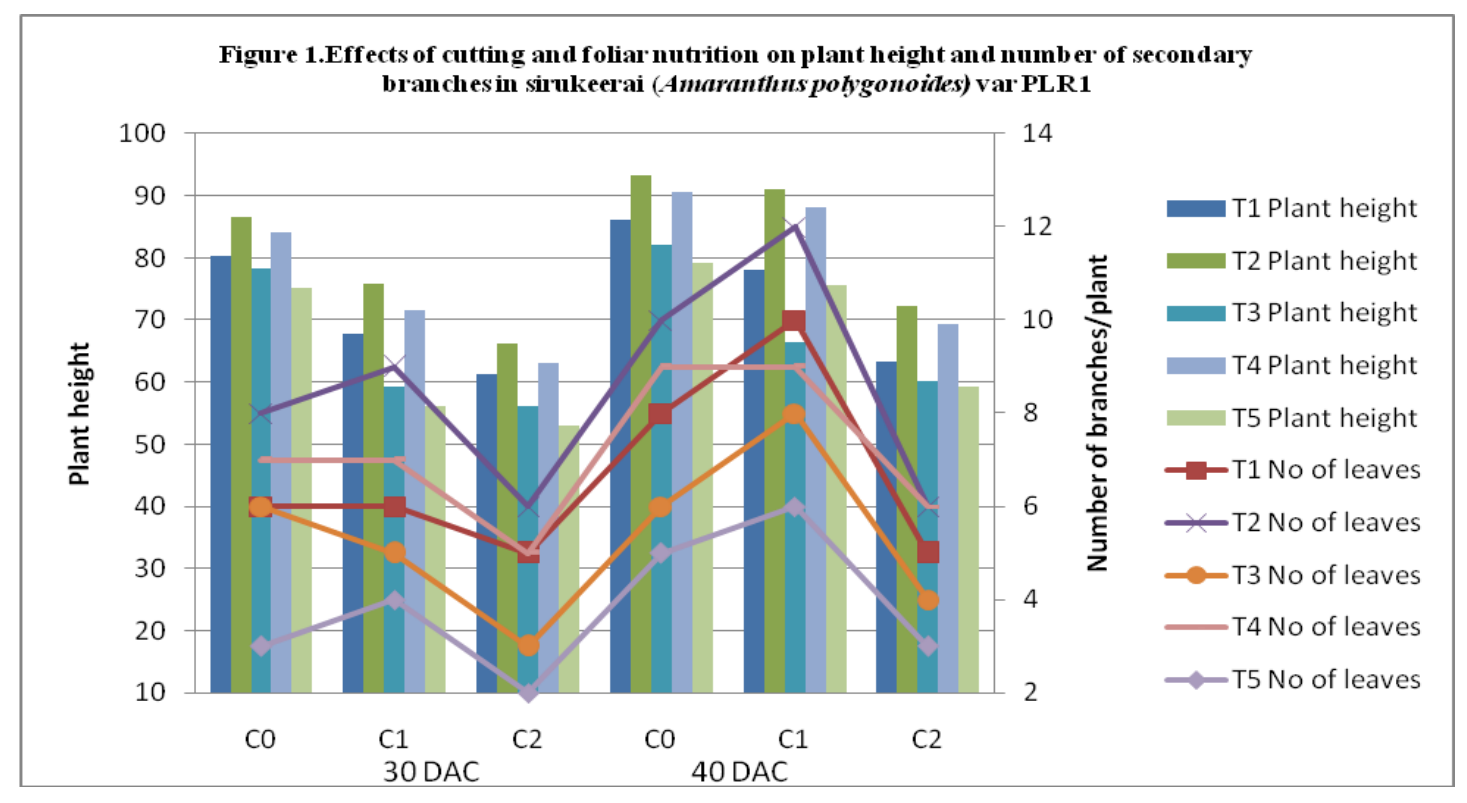


Fig. 2

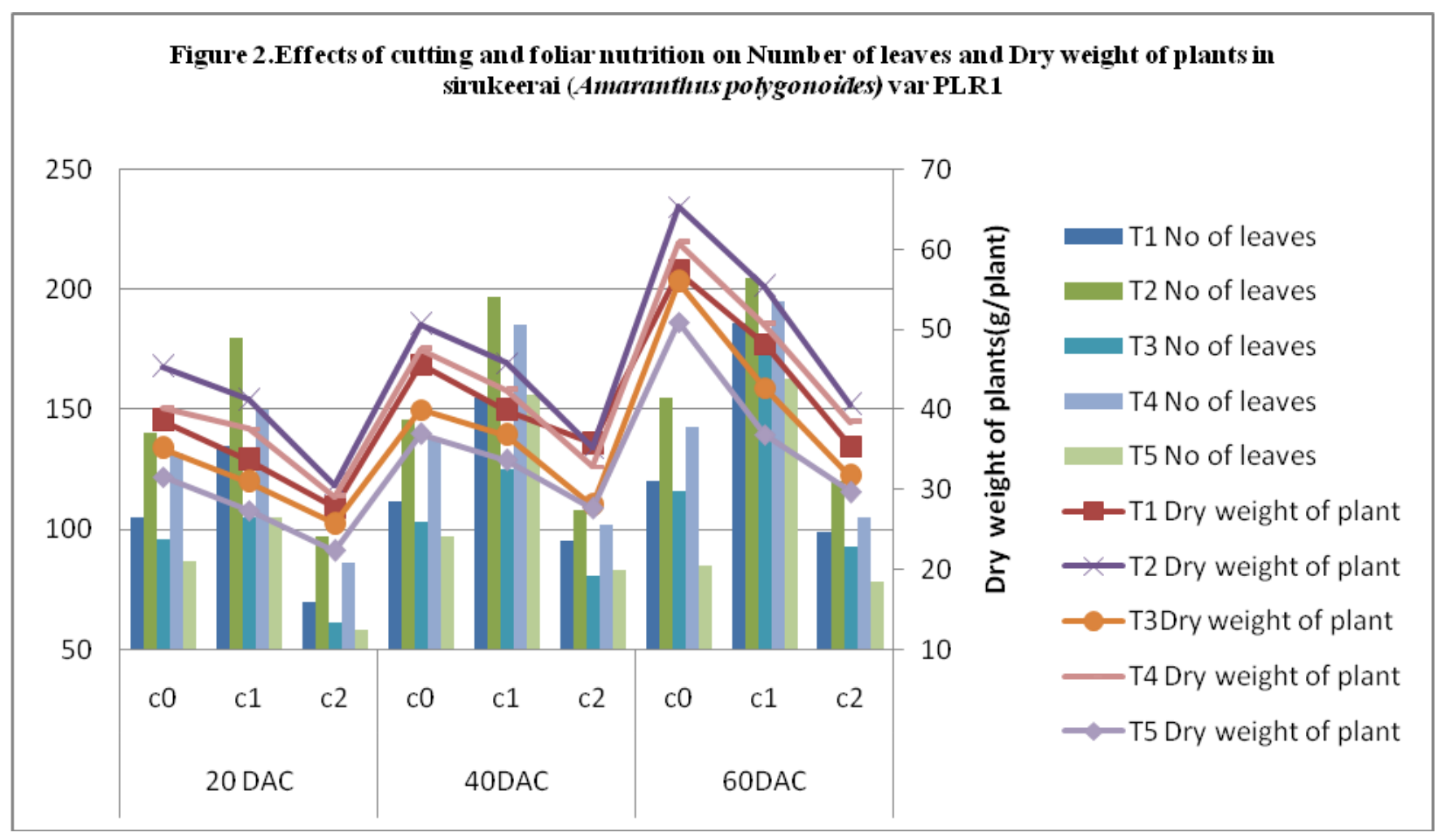


Fig.3

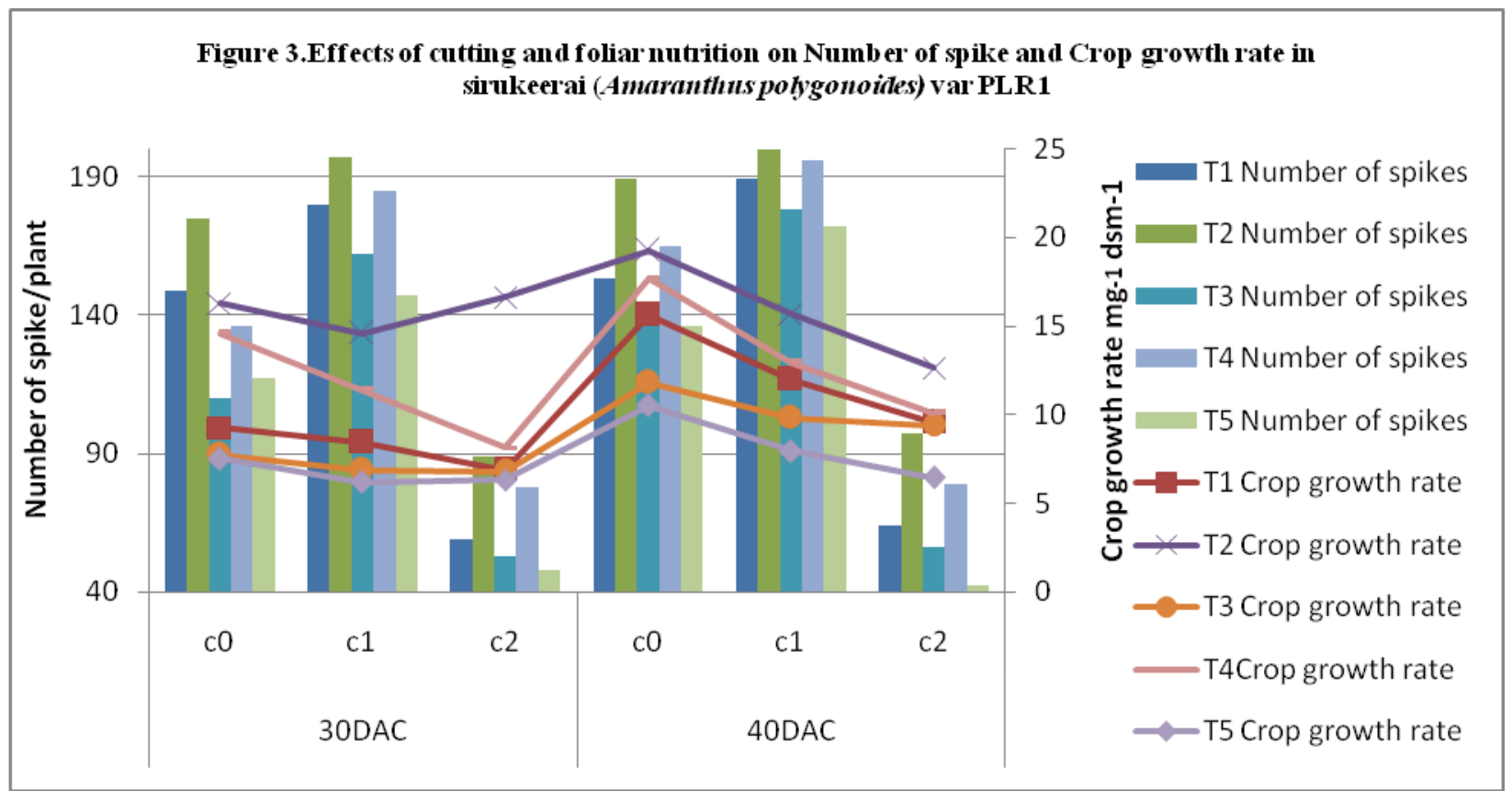


Nipping of tendrils in cowpea also recorded significantly lower plant height, more dry weight, maximum number of leaves and maximum number of branches (Reddy, 2005). It has been well established fact that arresting vegetative growth with pinching of apical bud in several flower and vegetative crops resulted in production of more number of productive branches which in turn influence the seed yield and yield attributes (Baboo \& Rana, 1995, Gill et al., 2001). The practice of pinching/pruning has proved to be effective in increasing the yield levels of different crops.

In the present study single cutting (205) recorded more number of spikes per plants than double cuttings (97) or no cutting (Fig3). Application of urea $2 \%$ further increased the number of spikes (155) compared to other treatments. Highest number of inflorescence was reported in coriander when single cutting at vegetative stage was imposed but not with double cuttings (Baboo \& Rana, 1995).

Seeds produced in a single plant increased up to $6.03 \mathrm{~g}$ from $3.68 \mathrm{~g}$ in control irrespective of cutting. Cutting once for green leaf collection has produced the highest seed yield $(5.60 \mathrm{~g})$ and the next best was no cutting (5.05g) followed by cutting twice (4.08).

Nutrient spray with urea has the potential to improve the seed yield even after cutting twice (5.24g) than control (2.81g).Increased photosynthetic area of the highly branched plants led to higher photosynthetic rate, better assimilation and accumulation of more photosynthates resulting into better seed development as evident with higher seed yield (673.2) (Table.2).

Similar increase in seed quality parameter with apical bud nipping was earlier revealed by Venkata Reddy et al., (1997) and Sajjan et al., (2003) in okra, Iyyannagouda (2003) in coriander and Sudarshan (2004) in fenugreek.
The increase in seed yield may also be due to the fact that leaf cutting at early stages of growth induces uniformity in growth, flowering and seed setting. Adverse effect of more than one cutting on seed yield might be due to injurious effects causing delay in flowering and seed set.

Foliar spray with urea $2 \%$ after single cutting at 20 DAS not only increased seed yield but also the quality parameters of the seeds, expressed as the highest 100 seed weight of $6.84 \mathrm{mg}$ which was $28-35 \%$ more than control.

Cutting recorded highest hundred seed weight (5.76 mg) compared to without cutting. In fenugreek cv. Pusa Early Bunching showed higher test weight in no leaf cuttings treatment than one and two leaf cutting levels, but at the same time leaf cutting once recorded increased leaf and seed yield (Rana et al., (2015).The test weight and seed yield were significantly influence by application of additional nutrients in fenugreek (Thapa and maity, 2003).

Cutting results in increased branching and vegetative growth thus increased biomass and seed yield. Hence cutting should be done at early stages of the crop not later than 20- 25 days after sowing and increased growth after pinching must be utilized for the conversion of yield parameters by way of application of urea $(2 \%)$ or SOP $(1 \%)$ at right stage of the crop.

\section{Acknowledgement}

The authors are very thankful to Department of seed science and technology, Agricultural College and Research institute, Madurai and Mother Teresa College of Agriculture, Pudhukottai for providing necessary facility to undertake the research Paper successfully. The authors are also thankful to Department of Agronomy Naini Agricultural Institute, Prayagraj, Sam Higginbottom University of 
Agriculture Technology and Sciences Prayagraj, (U.P.) India for providing necessary facility to undertake the studies.

\section{References}

Baboo, R. and Rana, N. S. (1995). Effect of cutting management, nitrogen, phosphrous, on growth, and yield of coriander (Coriandrum sativum). Indian Journal of Agronomy.40 (2), 253-255.

Gill, B. S., Randhawa, G. S., and Saini, S. S. (2001).Effect of sowing dates and herb cutting management on growth and yield of fenugreek (Trigonellafoenum-graecum). Indian Journal of Agronomy.46(2), 364-367.

Gomez, K. A., Gomez, A. A. Statistical Procedures for Agricultural Research. 2nd edn. John Wiley; New York: 1984. p. 680.

Gopal, M. (2012). Influence of topping and nutrient management practices on growth and seed yield of daincha (Sesbania aculeata (wild.) Pers). M.Sc., (Ag.) Thesis, TNAU, AC \& RI, Killikulam,

Groundnut (Arachis hypogaea L.).Mysore J. Agril. Sci., 15(2): 238-241.

ISTA. 2016. International rules for seed testing. switzerland: The International Seed Testing Association (ISTA).https://www.seedtest.org

Iyyanagouda S. Influence of spacing, nutrition, pinching and hormones on plant growth, seed yield and quality of coriander (Coriandrum sativum L.). M.Sc. (Agri.) Thesis, Univ. of Agric. Sci., Dharwad, Karnataka (India), 2003

M. A. Rahman and M. Jahiruddin. Effects of foliar application of Boron (B) on the grain set and yield of wheat (Triticum aestivum L.) American journal of Experimental Agriculture 12(2);1-8, Article no.AJEA.24286 ISSN :2231 -0606.

Reddy, S. S. and Patil, S. V. 1981. Effect of growth retardants on the yield and yield attributes of

S. C. Rana, V. K. Pandita and Sanjai Sirohi Influence of spacing and number of leaf cuttings on seed yield in fenugreek legume research - an international journal Volume 38 Issue 6 (2015) : 858-860.

Sajjan A, Jamadar M M. Influence of harvesting stages and drying methods on seed quality and seed mycoflora in okra seeds in northern dry zone of Karnataka. Karnataka J of Agric. Sci. 2003; 16(3):461-464.

Sajjan A, Jamadar M M. Influence of harvesting stages and drying methods on seed quality and seed mycoflora in okra seeds in northern dry zone of Karnataka. Karnataka J of Agric. Sci. 2003; 16(3):461-464

Singh, K K, Rawat J M S, Tomar, Y K, Kumar P B. Effect of IBA concentration on inducing rooting in stem cuttings of Thuja compacta under mist house condition. Horticulture Flora Research Spectrum. 2013; 2(1):30-34.

Srilatha, V., Reddy, Y. T. N., Upreti, K. K., and Jagannath, S. (2015). Pruning and paclobutrazol induced vigour, flowering and hormonal changes in mango (Mangifera indica L.). The Bioscan. 10(1): 161- 166.

Sudarshan J S. Influence of apical bud pinching, chemicals spray and physiological maturity on seed yield and quality of fenugreek (Trigonellafoenum -graceum L.). M.Sc. (Agri.) Thesis, Univ. of Agric. Sci., Dharwad, Karnataka (India), 2004.

Thapa, U. and Maity, T. K. (2003).Green and seed yield of fenugreek (Trigonellafoenum graecum L.) as affected by nitrogen, phosphorus and cutting management. $J$. of Inter academician.7 (3): 347-350.

Tiwari, R. S. Ankur Agarwal and Sengar, S. C. 2003. Effect of dates of sowing and number of cuttings on growth, seed yield and economics of coriander cv. Pant Haritima. Progressive Horticulture. 35 (1): 104-107

\section{How to cite this article:}

Pozhilarasi, S. and Geetha, R. 2021. Effect of Cutting and Foliar Nutrition on Seed Yield of Sirukeerai (Amaranthus polygonoides) var. PLR 1. Int.J.Curr.Microbiol.App.Sci. 10(12): 344352. doi: https://doi.org/10.20546/ijcmas.2021.1012.040 